\title{
Modificacion enzimatica de almidon de maiz y sus efectos en la viabilidad de la vitamina c
}

\author{
Enzymatic Modification of Corn Starch and its Effect on the Viability of Vitamin C \\ Leyva L.R. ${ }^{a}$, Palma R. H. M. ${ }^{a}$, Rodríguez H. A. I. ${ }^{a}$, López C. M. del R. ${ }^{a}, \operatorname{Vargas} T$. A. ${ }^{a}$
}

\begin{abstract}
:
In the present work, the effect of enzymatic hydrolysis ( $\alpha$-amylase and amyloglucosidase) at 16 and $20 \mathrm{~h}$ on the morphological, physicochemical and structural characteristics of corn starch, and the protective effect of this on ascorbic acid microcapsules was studied. The amylose content increased with respect to the hydrolysis time, observing several perforations, and a reduction in the size of the graph. The thermal properties show lower values of $\mathrm{H}$ and the increase in the gelatinization temperatures in the hydrolysed starches. Each starch modified in rubber with rubber was used to encapsulate ascorbic acid. They presented to the mayor the microcapsules formed with hydrolyzed starch at $16 \mathrm{~h}$ plus gum arabic, on the small granules and gum arabic (controls).
\end{abstract}

Keywords:

Vitamin C, enzymatically hydrolyzed starch, microcapsules, thermal properties

\section{Resumen:}

En el presente trabajo se estudió el efecto de la hidrólisis enzimática ( $\alpha$-amilasa y amiloglucosidasa) a las 16 y 20 h sobre las características morfológicas, fisicoquímicas y estructurales de almidón de maíz, y el efecto protector de este en microcápsulas de ácido ascórbico. El contenido de amilosa aumentó con respecto al tiempo de hidrólisis, observándose numerosas perforaciones, y una reducción en el tamaño del gránulo. Las propiedades térmicas mostraron menores valores de $\Delta \mathrm{H}$ y el aumento en las temperaturas de gelatinización en los almidones hidrolizados. Cada almidón modificado en mezcla con goma arábiga fue utilizado para encapsular ácido ascórbico. Presentaron mayor estabilidad las microcápsulas formadas con almidón hidrolizado a 16 h más goma arábiga, sobre las de gránulo pequeño y goma arábiga (controles).

Palabras Clave:

Vitamina $C$, almidón hidrolizado enzimáticamente, microcápsulas, propiedades térmicas

\section{INTRODUCTION}

Microencapsulation is a promising approach to protect bioactive compounds sensitive to the environment, reduce reactivity and improve stability, and / or allow a controlled release (Bansode et al., 2010). The published works report the incorporation of several bioactive molecules.

Although many encapsulation techniques have been developed, spray drying is the method commonly used. However, the choice of wall material can be critical, since it affects the encapsulation efficiency and the stability of the resulting microcapsules (Rosenberg et al., 1990). A good choice for a wall material should be based on its physicochemical properties.
In the group of biopolymers, enzymatically modified starches attract a lot of attention due to their great capacity of adsorption by the formed pores. They contain abundant pores from the surface to the center of the granules, which increase the specific surface, acting as excellent natural absorbers (Belingheri et al., 2015).

Vitamin $C$ is a bioactive compound historically known for its nutritional benefits for health. It has wide application as an antioxidant, and providing protection in the sensory and nutritional quality of food (Desai et al., 2006).

The aim of this work is characterize morphologically, physicochemically and structurally the enzymatically modified corn starch and evaluate the stability of the ascorbic acid microcapsules with starch previously modified and characterized in a mixture with gum arabic. 


\section{MATERIALS AND METHODS}

For the modification of the starch, the enzymes a-amylase and amyloglucosidase (10 U/g starch) were used in acetates buffer at $30^{\circ} \mathrm{C}$ and $380 \mathrm{rpm}$ for 16 and 20 hours. The apparent amylose content was determined by a reaction with $12 / \mathrm{KI}$. The enzymatically modified starches were characterized morphologically by scanning electron microscopy (SEM). The physicochemical properties were obtained by differential scanning calorimetry (DSC) and rapid viscosity analysis (RVA); and the structural, crystallinity and particle size were performed by X-ray diffraction and laser diffraction respectively.

The microcapsules were obtained by spray drying, then they were morphologically characterized by SEM and a stability test was carried out by means of an accelerated aging study $\left(52.5 \%\right.$ relative humidity and $\left.55^{\circ} \mathrm{C}\right)$ during 9 weeks of storage. The data were analyzed using an ANOVA with $95 \%$ confidence, when there were significant differences, a comparison of means was made with the Tukey test, with $\alpha \pm 0.05$.

\section{RESULTS AND DISCUSSION}

In the Fig. 1 corn starches enzymatically hydrolyzed are shown, it can be observed how the degree of hydrolysis was increasing according to the time of exposure of the enzymes, having a greater number of pores and eroded surface treatment of 20 hours, with different places of attack. Enzymatic hydrolysis is carried out in different parts of the starch, attacking both $\alpha-1,4$ and $\alpha-1,6$ bond of amylose and amylopectin, giving rise to smaller glucoses, maltoses and other oligosaccharides and dextrins. Several channels were formed throughout the starch area, as reported by Spinelli et al., (2013). Aggarwal \& Dollimore (2000), observed an increase in the size of the pores, when the concentration of amyloglucosidase increased, until a break, giving rise to large irregular holes and a disrupted structure. Jayakody \& Hoover (2002) postulated that the presence of pores or channels on the surface of the granules, as in corn starch, facilitates the work of the enzymes towards the interior of the granule, which makes it more susceptible to hydrolysis.

In the determination of the amylose content, a statistically significant increase $(p<0.05)$ can be observed (Fig. 2) as the enzymatic hydrolysis time increased, giving as results $18.34 \pm 0.77,58.94 \pm 3.96$ and $74.09 \pm 2.41$ for native starches. hydrolyzed 16 and $20 \mathrm{~h}$ respectively. This increase was largely due to the hydrolyzed fractions, glucose and maltose, which formed when the enzymes acted. Chung et al., (2015) observed a high content of amylose in rice after enzymatic hydrolysis with amylolitic enzymes, he attributes the increase of this polymer to the action of amyloglucosidase.

The particle size of the native corn starch and enzymatically hydrolysed for 16 and $20 \mathrm{~h}$ time were 15.83 , 14.97 and $14.72 \mu \mathrm{m}$ respectively, did not present statistically significant differences $(p<0.05)$; although the tendency was to decrease with hydrolysis time, this change is due to the internal and superficial erosions due to the enzymatic attack of a-amylase and amyloglucosidase. The results are similar to those reported in the literature (Tester \& Karkalas, 2002).

The X-ray diffraction patterns of the native and modified starches are shown in Fig. 3. The native corn starches and the modified starches showed a type A diffraction pattern, which is typical of cereals, and is characterized by presence of peaks of greater intensity of diffraction for the angles $2 \theta=15,17,18$ and $23^{\circ}$. It can be observed in the diffractogram that the starch that showed the highest crystallinity was the hydrolyzate enzymatically for $20 \mathrm{~h}$, followed by the hydrolyzate of $16 \mathrm{~h}$ and with a lower percentage the native with values of $60.77,40.09$ and $28.14 \%$ respectively. Authors have postulated that the breaking of the starch chains in the amorphous zones allows an extensive hydrolysis, producing a more crystalline structure (Kainuma \& French, 1971).

In DSC, the thermal properties of the modified starches showed lower values of $\Delta \mathrm{H}$ and an increase in the temperatura of gelatinization (Table I), showing significant statistical differences $(p<0.05)$ between the hydrolysed starches and the native. The $\Delta \mathrm{H}$ values were 10.5, 7.0 and $9.0 \mathrm{~J} / \mathrm{g}$ and the gelatinization temperatures of $72.1,73.3$ and $73.2^{\circ} \mathrm{C}$ for native starches and hydrolyzed at $16 \mathrm{~h}$ and $20 \mathrm{~h}$ respectively. The decrease in $\Delta \mathrm{H}$ indicates that porous starches require less energy to promote starch gelatinization, ie the energy needed to unwind the unstable double helices during gelatinization (Sandhu \& Singh, 2007).

As for the microcapsules, it can be observed that most of the pores are covered on the surface, with a slight agglomeration (Fig. 1). The starch granules have an undefined structure, although with the same tendency as regards the distribution. In Fig. 4, it can be observed how the microcapsules of starch hydrolyzed for 16 hours have a better stability during storage under accelerated aging conditions, conserving $17.6 \%$ and $12 \%$ of ascorbic acid encapsulated initially in weeks 6 and 8 respectively.

\section{CONCLUSIONS}

Changes were made in the morphological, structural and physicochemical characterization between native and hydrolyzed starches. The microcapsules with hydrolyzed starch for 16 hours showed greater stability during the accelerated aging test compared to the controls. In this 
study it is concluded that the enzymatic perforation of the starches could be a good alternative to encapsulate bioactive compounds favoring the stability regarding the storage time.

\section{References}

Aggarwall, P. \& Dollimore, D. (1998). A thermal analysis investigation of partially hydrolyzed starch. Thermochimica Acta, 319, pp. 17-25.

Bansode, S. S., Banarjee, S. K., Gaikwad, D. D., Jadhav, S. L., Thorat, R. M, Microencapsulation: a review. International Journal of Pharmacological Sciences. 2010, 1, 38-43.

Belingheri, C., Giussani, B., Rodriguez-Estrada, M. T., Ferrillo, A., Vittadini, E, Oxidative stability of high-oleic sunflower oil in a porous starch carrier. Food Chemistry. 2015, 166, 346-351.

Chung, Ch., Othman, Z. \& Jau, L. (2015). Gamma irradiation of corn starches with different amylose to amylopectin ratio. Journal Food Science Technology, 52(10), pp. 6218-6229.

Cooke, D. \& Gidley, M. (1992). Loss of crystalline and molecular order during starch gelatinisation: origin of the enthalpic transition. Carbohydrate Research, 227 , pp. 103-112.

Desai, K. G., Liu, C., Park, H. J, Characteristics of vitamin C encapsulated tripolyphosphate-chitosan microspheres as affected by chitosan molecular weight. Journal of Microencapsulation 2006, 23, 79-90.

Jayakody, L. \& Hoover, R. (2002). The effect of lintinerization on cereal starch granules. Journal Food Research Internernational, 35, pp. 665-680.

Kainuma, K. \& French, D. (1971). Nageli amylodextrin and its relationship to starch granule structure. I. Preparation and properties of amylodextrins from varios starch types. Biopolymers, 10, pp.1673-1680.

Rosenberg, M., Kopelman, I. J., Talmon, Y, Factors affecting retention in spray-drying microencapsulation of volatile materials. Journal of Agricultural and Food Chemistry. 1990, 38, 1288-1294.

Singh, N. \& Sandhu, S. (2007). Some properties of corn starches II: Physicochemical, gelatinization, retrogradation, pasting and gel textural properties. Food Chemistry, 101, pp. 1499-1507.

Spinelli, B., Guérente, C., Armand, S., Lenouvel, F., Labbé, P., \& Fort, S. (2013). Functional characterization of starch degrading enzymes using quartz crystal microbalance with dissipation monitoring, Sensors and Actuators B, 176, pp. 1038-1043.

Tester, R. \& Karkalas, J. (2002). Starch In: Steinbüchel, A. (Series Ed.), Vandamme, J., de Baets, S. \& Steinbüchel, A. (Vol. Eds.), Biopolymers, Vol. 6, Polysaccharides. II. Polysaccharides from Eukaryotes, Wiley-VCH, Weinheim, pp. 381-438.

Table I. Parameters of thermal profile analysis, measurements made to starch treatments, using differential scanning calorimetry (DSC) ${ }^{1}$.

\begin{tabular}{|c|c|c|c|c|c|}
\hline Starch & To $\left({ }^{\circ} \mathrm{C}\right)$ & $\operatorname{Tp}\left({ }^{\circ} \mathrm{C}\right)$ & $\operatorname{Tc}\left({ }^{\circ} \mathrm{C}\right)$ & $\Delta \mathrm{H}(\mathrm{J} / \mathrm{g})$ & Tc-To \\
\hline AMN & $68.52 \pm 0.51^{a}$ & $72.43 \pm 0.36^{a}$ & $77.29 \pm 0.43$ & $10.30 \pm 0.4^{a}$ & $8.77 \pm 0.47$ \\
\hline AM16H & $69.42 \pm 0.25^{b}$ & $73.08 \pm 0.16^{b}$ & $78.36 \pm 0.33$ & $7.83 \pm 0.44^{b}$ & $9.10 \pm 0.47$ \\
\hline $\mathrm{AM} 2 \mathrm{OH}$ & $69.31 \pm 0.23^{b}$ & $73.15 \pm 0.25^{b}$ & $77.7 \pm 0.12$ & $8.63 \pm 0.48^{b}$ & $8.43 \pm 0.34$ \\
\hline
\end{tabular}

${ }^{1}$ Data are the means of three repetitions \pm standard deviation, different superscripts per row represent significant statistical differences $(P<0.05)$. $T p=$ Peak temperature, $\Delta \mathrm{H}=$ Enthalpy change. $A M N=$ Native corn starch, $\mathrm{AM} 16 \mathrm{H}=$ Corn starch enzymatically hydrolyzed for 16 hours, AM20H = Corn starch enzymatically hydrolyzed for 20 hours. 